\title{
Bioactive Metabolites of Aspergillus neoniger, an Endophyte of the Medicinal Plant Ficus carica
}

\begin{abstract}
RANDA ABDOU ${ }^{1 *}$, ALAA M ALQAHTANI² AND G. H. ATTIA ${ }^{3}$
Department of Pharmacognosy, Faculty of Pharmacy, Umm Al-Qura University, Makkah 21514, Kingdom of Saudi Arabia, ${ }^{1}$ Department of Pharmacognosy, Faculty of Pharmacy, Helwan University, Cairo 45820, Egypt, ${ }^{2}$ Department of Pharmaceutical Chemistry, Faculty of Pharmacy, Umm Al-Qura University, Makkah-21514, Kingdom of Saudi Arabia, ${ }^{3}$ Department of Pharmacognosy, College of Pharmacy, Najran University, Najran-61961, Kingdom of Saudi Arabia
\end{abstract}

\section{Abdou et al.: Aurasperones from the endophyte Aspergillus neoniger}

Endophytes are considered as a rich source of bioactive natural products. Many plants have not been investigated for their endophytic content yet, such as the medicinal plant Ficus carica. Recent studies confirmed antimicrobial and anticancer activities for the plant extract. To find out if its endophytes contribute to its reported activities, the bioactive endophyte Aspergillus neoniger was selected for investigation of its metabolites since it exerted antimicrobial and anticancer activities in preliminary screening assays. The fungal extract was subjected to bioactivity guided chromatographic fractionation for isolation of its bioactive metabolites. This resulted in the identification of four aurasperones (asperpyrone $D$, aurasperone $D$, dianhydroaurasperone $C$, aurasperone $A$ ) through spectroscopic analysis. Aurasperone $D$ and asperpyrone $D$ were found to be cytotoxic against human cervical cancer cells $(50 \%$ cytotoxic concentration $=4.4 \mu \mathrm{g} \mathrm{ml}^{-1}$ and $3.0 \mu \mathrm{g} \mathrm{ml}^{-1}$ respectively). Aurasperone $\mathrm{D}$ exerted strong antiproliferative effect against human immortal erythroleukaemia cells 562 and human umbilical vein endothelial cells (concentration at which $50 \%$ growth inhibition achieved was 5.3 and $4.7 \mu \mathrm{g} \mathrm{ml}^{-1}$ ) as well as asperpyrone D (concentration at which $50 \%$ growth inhibition achieved was 4.9 and $5.4 \mu \mathrm{g} \mathrm{ml}^{-1}$ ). Dianhydroaurasperone $\mathrm{C}$ and aurasperone $\mathrm{A}$, on the contrary, showed weak cytotoxic and antiproliferative effects. All compounds were tested for antimicrobial activity against several test strains including the plant pathogen Fusarium oxysporum. Results revealed that aurasperone $D$ and asperpyrone $D$ to be most active which suggests potential protective role of this endophyte on its host plant. These results suggest possible partial contribution of Aspergillus neoniger to the reported activity of the host plant

Key words: Endophyte, Ficus carica, Aspergillus neoniger, anticancer, antifungal

Endophytes are found in almost all plants studied so far. They are microorganisms living inside plant tissues without diseasing them ${ }^{[1]}$ and are considered as promising sources of bioactive natural products ${ }^{[2]}$. Since many years, plants and microorganisms represent rich sources of effective drugs with potent anticancer activity $^{[3]}$. Endophytic fungi are considered as a promising source of bioactive natural products, since it has been reported that fungi produce more metabolites than other endophytes ${ }^{[4]}$. According to previous studies the biological activity and growth conditions of a plant are important criteria for its selection for endophytic investigation ${ }^{[5]}$. The genus Ficus represents one of the largest genera of medicinal plants. Many biological activities have been reported for it such as laxative, antiinflammatory, anti-rheumatic and anti-oxidant effects ${ }^{[6]}$. Previously reported studies revealed Ficus species

*Address for correspondence

E-mail: rfabdou@uqu.edu.sa

January-February 2021 to be a rich source of flavonoids, polyphenols and bioactive compounds such as glycosides, $\beta$-setosterols and xanthotoxol. In addition, studies reported the improvement of gastrointestinal, cardiovascular, respiratory disorders, ulcerative diseases, and cancers by dried figs ${ }^{[7]}$. In traditional herbal medicine, Ficus species were used to exert various biological effects such as hypotensive, antidiabetic and antibacterial actions. Furthermore, studies reported their application as anti-inflammatory agents in infections of the urinary tract as well as in reduction of fever and for

This is an open access article distributed under the terms of the Creative Commons Attribution-NonCommercial-ShareAlike 3.0 License, which allows others to remix, tweak, and build upon the work non-commercially, as long as the author is credited and the new creations are licensed under the identical terms

Accepted 23 January 2021

Revised 25 September 2020

Received 06 January 2020 Indian J Pharm Sci 2021;83(1):101-109 
treatment of tuberculosis. Topically, they have been administered for the treatment of skin conditions like tinea and eczema ${ }^{[8-10]}$. Furthermore, a hepatoprotective effect for Ficus ingens extract against liver damage in albino rats was reported. In addition, antioxidant, hypoglycemic, cancer suppressive, antiviral and anthelmintic effects were previously detected for the extract of Ficus carica ${ }^{[1,6]}$ and antitumor effect for Ficus benghalensis ${ }^{[12]}$. So far investigation of Ficus species focused mainly on the plant itself, but its endophytes were rarely studied. A recent study reported the frequency of endophyte colonization in the different plant parts of Ficus benghalensis growing in India and stated that the growth environment and tissue type of the host plant determine endophyte composition in that host ${ }^{[13]}$. More recently Ficus carica growing in India was studied for the potential use of its endophytes as biocontrol agents and their activity against phytopathogens was examined ${ }^{[14]}$. Now the question arises about the role of endophytes of Ficus carica in its biological actions. Previous studies suggested that endophytes might contribute to the biological effects observed for host plants ${ }^{[15]}$.

The antimicrobial activity of Ficus carica was confirmed by a study testing the effect of the plant extract on several bacterial strains (Escherichia coli, Staphylococcus aureus, Streptococcus sanguinis, Streptococcus criceti, Streptococcus gordonii and Streptococcus anginosus). Results revealed potent antimicrobial activity for the methanolic plant extract with minimum inhibitory concentration (MIC) values ranging from 0.313 to $5 \mathrm{mg} / \mathrm{ml}$ against the different strains $^{[16]}$.

Another study investigated the antifungal effects of Ficus carica extracts and revealed growth inhibition of Candida albicans and Microsporum canis by the plant extract with MIC of $500 \mu \mathrm{g} / \mathrm{ml}$ and $75 \mu \mathrm{g} / \mathrm{ml}$, respectively ${ }^{[17]}$. Furthermore, the anticancer activity of the plant was recently studied on Huh7it liver cancer cells and results revealed the half maximal inhibitory concentration $\left(\mathrm{IC}_{50}\right.$ ) value of $>653 \mu \mathrm{g} / \mathrm{ml}$ for the extract of the plant's leaves ${ }^{[18]}$. Taking the reported biological activities of Ficus carica ${ }^{[6]}$ into consideration and its special growing conditions in Makkah, Kingdom of Saudi Arabia (KSA), it was selected for the study of its endophytes. This study reports the isolation, investigation of the anticancer and antimicrobial activities of metabolites of the endophyte Aspergillus neoniger isolated from Ficus carica growing in KSA.

\section{MATERIALS AND METHODS}

\section{Collection of the plant and isolation of the endophyte:}

Ficus carica family Moraceae was collected near Makkah, KSA. Plant materials were reduced in size, washed, surface sterilized and dried under a laminar flow hood. Using a sterile scalpel, the external tissues of the leaves of Ficus carica were removed and internal tissues were dissected under sterile conditions. The endophyte was isolated and cultivated as previously reported and was identified by internal transcribed spacer (ITS) sequence comparison ${ }^{[19,20]}$.

\section{Fermentation, extraction and fractionation of the endophyte:}

The fungus was cultivated in a medium of potato dextrose agar at $23^{\circ}$ for $2 \mathrm{w}$. The mycelium of each plate was employed to inoculate a 11 Erlenmeyer flask containing $250 \mathrm{ml}$ of the Pridham-Gottlieb medium (MPG) composed of glucose $(10 \mathrm{~g} / \mathrm{l})$, malt extract $(20 \mathrm{~g} / 1)$, soybean flour $(2 \mathrm{~g} / 1)$, yeast extract $(1 \mathrm{~g} / \mathrm{l})$, potassium dihydrogen phosphate $\left(\mathrm{KH}_{2} \mathrm{PO}_{4}\right)(1 \mathrm{~g} / \mathrm{l})$ and Magnesium sulfate heptahydrate $\left(\mathrm{MgSO}_{4} \cdot 7 \mathrm{H}_{2} \mathrm{O}\right)$ $(0.5 \mathrm{~g} / \mathrm{l})$. Incubation of a 601 stationary culture was carried out for $3 \mathrm{w}\left(23^{\circ}\right)$ under static conditions. The culture filtrate and mycelium were homogenized, then macerated for $24 \mathrm{~h}$ in $200 \mathrm{ml}$ ethyl acetate and afterwards decanted and collected. The obtained extract was evaporated to dryness and then defatted with n-hexane. Agar diffusion assay was used to test the antimicrobial action of the strain extract against several test strains (fig. 1 and fig. 2). Fractionation of the obtained extract chromatographically started on Silica gel as a stationary phase in open column using a mobile phase consisting of a mixture of chloroform and methanol in a proportion of 9 to 1 whose polarity was increased

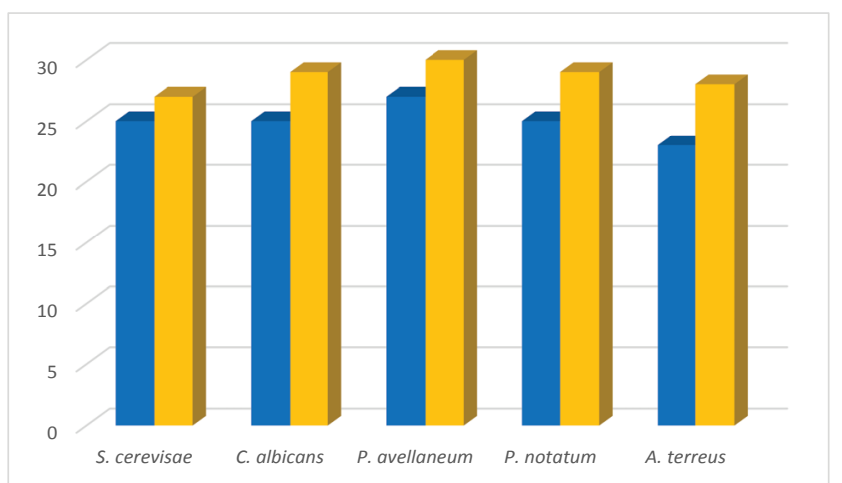

Fig. 1: Antifungal activity of Aspergillus neoniger extract Antifungal activity of the $(\square)$ strain extract is measured in terms of the diameter of the inhibition zone in millimeters using ( $\square$ ) nystatin as a positive control 


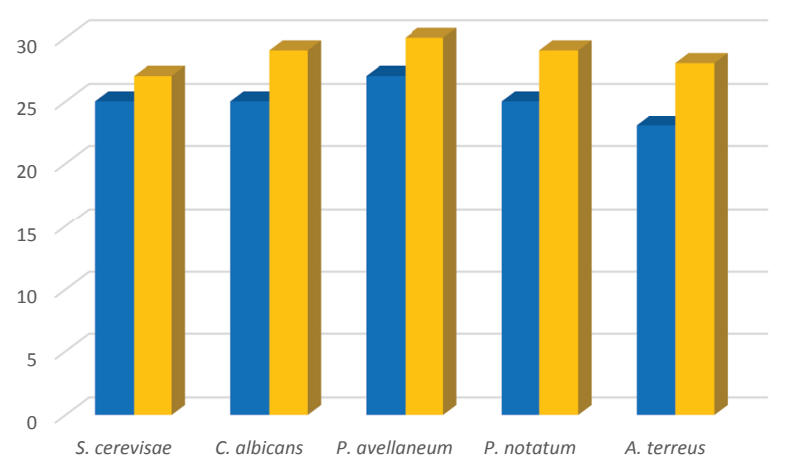

Fig. 2: Antibacterial activity of Aspergillus neoniger extract Antibacterial activity of the $(\square)$ strain extract is measured in terms of the diameter of the inhibition zone in millimeters using ( $\square$ ) ciprofloxacin as a positive control

stepwise till elution with $100 \%$ methanol. Additional fractionation steps were performed using Sephadex lipophilic and hydrophilic (LH)-20 as a stationary phase and methanol as an eluent. Final purification steps were carried out using preparative high performance liquid chromatography (HPLC) starting with a mobile phase composed of a solvent system of $25 \%$ acetonitrile in water $\left(\mathrm{H}_{2} \mathrm{O}\right)$ and ending with elution with $100 \%$ acetonitrile. This resulted in the identification of four aurasperones: dianhydroaurasperone $\mathrm{C}$ (10 mg), aurasperone D (6 mg), asperpyrone D (5 mg) and aurasperone $\mathrm{A}(7 \mathrm{mg})$ by spectroscopic analysis of the purified metabolites.

Dianhydroaurasperone C: Yellowish powder, Infrared (IR) (film) $\mathrm{v}_{\text {max }}, 3455$ (broad), 1677, 1632, 1551, 1485, $1422,1022 \mathrm{~cm}^{-1}$; Ultraviolet (Methanol $\left.(\mathrm{MeOH})\right) \lambda_{\max }$ (log $\epsilon$ ): 224 (4.35), 254 (4.42), 281 (4.92), 324 (3.56), $406(3.75) \mathrm{nm}$; High resolution electrospray ionisation mass spectrometry (HRESIMS): $\mathrm{m} / \mathrm{z} 557.1540[\mathrm{M}+\mathrm{H}]^{+}$ calculated as 557.1545 for 8 '-O-demethylnigerone $\left(\mathrm{C}_{31} \mathrm{H}_{24} \mathrm{O}_{10}\right)$. Nuclear magnetic resonance (NMR) data is shown in Table 1 .

Aurasperone D: Yellowish solid, IR (film) $\mathrm{v}_{\text {max }}, 3400$ (broad), 1655, 1600, 1582, 1496, 1405, $1019 \mathrm{~cm}^{-1}$; UV $(\mathrm{MeOH}) \lambda_{\text {max }}(\log \epsilon)$ 235-240 (4.71), 281 (4.70), 320325 (4.19), 381 (3.86) nm; HRESIMS m/z 557.1050 $[\mathrm{M}+\mathrm{H}]^{+}$, calculated as 557.1054 for $\mathrm{C}_{31} \mathrm{H}_{24} \mathrm{O}_{10}$. NMR data is shown in Table 1.

Aurasperone A: Yellowish powder, IR (film) $\mathrm{v}_{\text {max }}: 3352$ (broad), 1682, 1631, 1555, 1472, 1403, $1056 \mathrm{~cm}^{-1}$; UV (MeOH) $\lambda_{\text {max }}(\log \epsilon) 226$ (4.53), 259 (4.43), 281 (4.54), 326 (3.91), 400 (3.67) nm; HRESIMS m/z 571.1053 $[\mathrm{M}+\mathrm{H}]^{+}$calculated as 571.1056 for Aurasperone A $\left(\mathrm{C}_{32} \mathrm{H}_{26} \mathrm{O}_{10}\right)$. NMR data is shown in Table 2 .
Asperpyrone D: Yellowish powder, IR (film) $\mathrm{v}_{\max }$ : 3426, 2927, 2859, 2364, 2339, 1654, 1615, 1572, 1425, 1382, 1260, 1205, 1167 and $1066 \mathrm{~cm}^{-1}$; UV $(\mathrm{MeOH})$ $\lambda_{\max }$ (log €): 385 (3.85), 280 (4.67), 249 (4.63), 226 (4.53) nm; HRESIMS m/z 557.1431 [M+H] ${ }^{+}$calculated as 557.1448 for $\mathrm{C}_{31} \mathrm{H}_{24} \mathrm{O}_{10}$. NMR data is shown in Table 2.

\section{TABLE 1: ${ }^{1} \mathrm{H}$ NMR DATA $(300 \quad \mathrm{MHz}$, DEUTERATED DIMETHYL SULFOXIDE (DMSO-D6)) FOR DIANHYDROAURASPERONE C AND AURASPERONE D}

\begin{tabular}{|c|c|c|}
\hline Position & $\begin{array}{c}\delta^{1} \mathrm{H}(\mathrm{J} \text { in } \mathrm{Hz}) \\
\text { (dianhydroaurasperone } \mathrm{C})\end{array}$ & $\begin{array}{c}\delta^{1} \mathrm{H}(\mathrm{J} \text { in } \mathrm{Hz}) \\
\text { (aurasperone } \mathrm{D})\end{array}$ \\
\hline \multicolumn{3}{|l|}{2} \\
\hline 3 & $6.22, \mathrm{~s}$ & $6.21, \mathrm{~s}$ \\
\hline \multicolumn{3}{|l|}{4} \\
\hline \multicolumn{3}{|l|}{$4 a$} \\
\hline \multicolumn{3}{|l|}{5} \\
\hline \multicolumn{3}{|l|}{$5 a$} \\
\hline \multicolumn{3}{|l|}{6} \\
\hline 7 & & $6.52, \mathrm{~s}$ \\
\hline \multicolumn{3}{|l|}{8} \\
\hline 9 & & $7.12, \mathrm{~s}$ \\
\hline \multicolumn{3}{|l|}{$9 a$} \\
\hline \multicolumn{3}{|l|}{10} \\
\hline \multicolumn{3}{|l|}{$10 a$} \\
\hline $\mathrm{CH}_{3}-2$ & & $2.40, \mathrm{~s}$ \\
\hline $\mathrm{OH}-5$ & $15.11, \mathrm{~s}$ & $15.12, \mathrm{~s}$ \\
\hline $\mathrm{OCH}_{3}-6$ & $3.40, \mathrm{~s}$ & \\
\hline $\mathrm{OCH}_{3}-8$ & & $3.55, \mathrm{~s}$ \\
\hline $\mathrm{OH}-8$ & $14.90, \mathrm{~s}$ & \\
\hline \multicolumn{3}{|l|}{$2^{\prime}$} \\
\hline $3^{\prime}$ & $6.21, \mathrm{~s}$ & $6.20, \mathrm{~s}$ \\
\hline \multicolumn{3}{|l|}{$4^{\prime}$} \\
\hline \multicolumn{3}{|l|}{5} \\
\hline \multicolumn{3}{|l|}{ 5'a } \\
\hline \multicolumn{3}{|l|}{$6^{\prime}$} \\
\hline $7^{\prime}$ & $6.64, d(2.4)$ & $6.25, \mathrm{~d}(2.1)$ \\
\hline \multicolumn{3}{|l|}{$8^{\prime}$} \\
\hline 9' & $6.15, \mathrm{~d}(2.3)$ & $7.37, \mathrm{~d}(2.1)$ \\
\hline \multicolumn{3}{|l|}{ 9'a } \\
\hline \multicolumn{3}{|l|}{$10^{\prime}$} \\
\hline \multicolumn{3}{|l|}{$10 ’ a$} \\
\hline $\mathrm{CH}_{3}-2^{\prime}$ & $2.13, \mathrm{~s}$ & $2.15, \mathrm{~s}$ \\
\hline $\mathrm{OH}-5^{\prime}$ & & $14.90, \mathrm{~s}$ \\
\hline $\mathrm{OCH}_{3}-6$ & $3.65, \mathrm{~s}$ & $3.63, \mathrm{~s}$ \\
\hline $\mathrm{OCH}_{3}-8^{\prime}$ & $3.94, \mathrm{~s}$ & $3.97, \mathrm{~s}$ \\
\hline $\mathrm{OCH}_{3}-10^{\prime}$ & & \\
\hline
\end{tabular}


TABLE 2: ${ }^{1} \mathrm{H}$ NMR DATA (300 MHz, DMSO-D6) FOR AURASPERONE A AND ASPERPYRONE D

\begin{tabular}{|c|c|c|}
\hline Position & $\begin{array}{c}\delta^{1} \mathrm{H}(\mathrm{J} \text { in } \mathrm{Hz}) \\
\text { (aurasperone } \mathrm{A})\end{array}$ & $\begin{array}{c}\delta^{1} \mathrm{H}(\mathrm{J} \text { in } \mathrm{Hz}) \\
\text { (asperpyrone } \mathrm{D})\end{array}$ \\
\hline \multicolumn{3}{|l|}{2} \\
\hline 3 & $6.31, \mathrm{~s}$ & $6.20, \mathrm{~m}$ \\
\hline \multicolumn{3}{|l|}{4} \\
\hline \multicolumn{3}{|l|}{$4 a$} \\
\hline \multicolumn{3}{|l|}{5} \\
\hline \multicolumn{3}{|l|}{$5 a$} \\
\hline \multicolumn{3}{|l|}{6} \\
\hline \multicolumn{3}{|l|}{7} \\
\hline \multicolumn{3}{|l|}{8} \\
\hline 9 & $7.39, \mathrm{~s}$ & $7.10, d(9.6)$ \\
\hline \multicolumn{3}{|l|}{$9 a$} \\
\hline 10 & $7.40, \mathrm{~s}$ & $7.25, d(8.1)$ \\
\hline \multicolumn{3}{|l|}{$10 a$} \\
\hline $\mathrm{CH}_{3}-2$ & $2.13, \mathrm{~s}$ & $2.40, \mathrm{~s}$ \\
\hline $\mathrm{OH}-5$ & & $14.80, \mathrm{~s}$ \\
\hline $\mathrm{OCH}_{3}-6$ & $3.64, \mathrm{~s}$ & $3.57, d(5.2)$ \\
\hline \multicolumn{3}{|l|}{$\mathrm{OCH}_{3}-8$} \\
\hline $\mathrm{OH}-8$ & & $15.10, \mathrm{~s}$ \\
\hline \multicolumn{3}{|l|}{$2^{\prime}$} \\
\hline $3^{\prime}$ & $6.21, \mathrm{~s}$ & $6.50, d(2.3)$ \\
\hline \multicolumn{3}{|l|}{$4^{\prime}$} \\
\hline \multicolumn{3}{|l|}{$5^{\prime}$} \\
\hline \multicolumn{3}{|l|}{ 5’a } \\
\hline \multicolumn{3}{|l|}{$6^{\prime}$} \\
\hline $7^{\prime}$ & $6.15, d(2.2)$ & $6.62, d(2.22)$ \\
\hline \multicolumn{3}{|l|}{$8^{\prime}$} \\
\hline $9^{\prime}$ & $6.58, d(2.1)$ & 6.15 , dd $(2.13 ; 2.23)$ \\
\hline \multicolumn{3}{|l|}{ 9'a } \\
\hline \multicolumn{3}{|l|}{$10^{\prime}$} \\
\hline \multicolumn{3}{|l|}{10 'a } \\
\hline $\mathrm{CH}_{3}-2^{\prime}$ & $2.18, \mathrm{~s}$ & $2.55, \mathrm{~s}$ \\
\hline $\mathrm{OH}-5$ & $14.92, \mathrm{~s}$ & $13.29, \mathrm{~s}$ \\
\hline $\mathrm{OCH}_{3}-6$ & $3.84, \mathrm{~s}$ & \\
\hline $\mathrm{OCH}_{3}-8$ & $3.95, \mathrm{~s}$ & $3.42, d(5.24)$ \\
\hline $\mathrm{OCH}_{3}-10$ & & $4.07, \mathrm{~d}(5.26)$ \\
\hline
\end{tabular}

\section{Antimicrobial screening:}

Antmicrobial activities were studied by agar diffusion tests and MIC was determined according to the literature $^{[21,22]}$.
Anticancer assay:

Cancer cell lines (Human Umbilical Vein Endothelial Cells (HUVEC), human immortal erythroleukaemia cells (K-562) and human cervical cancer (HeLa) cells were cultured in Dulbecco's Modified Eagle's medium (DMEM), Roswell Park Memorial Institute (RPMI) 1640 and RPMI 1640 respectively. The cell culture medium was supplemented with $10 \mathrm{ml} \mathrm{l}^{-1}$ ultraglutamine 1, $500 \mu \mathrm{l} \mathrm{l}^{-1}$ gentamicin sulfate, and $10 \%$ heat inactivated fetal bovine serum at $37^{\circ}$ in high density polyethylene flasks and the anticancer assay was performed as previously reported ${ }^{[19,23]}$.

\section{RESULTS AND DISCUSSION}

The endophyte was cultivated on small scale in different culture media for prescreening of its antimicrobial and cytotoxic activities. Results revealed the extract of the strain cultivated in MPG medium to be the most active. Potent cytotoxic effects were detected for the crude extract of the endophyte against HeLa (50\% cytotoxic concentration $\left.\left(\mathrm{CC}_{50}\right)=4.2 \mu \mathrm{g} \mathrm{ml}^{-1}\right)$ in addition to anti proliferative effects against K-562 and HUVEC cell lines (Concentration at which $50 \%$ growth inhibition was achieved $\left(\mathrm{GI}_{50}\right)=3.9$ and $3.8 \mu \mathrm{g} \mathrm{ml}^{-1}$ respectively). The extract exerted antimicrobial activity against several fungal (fig. 1) and bacterial strains (fig. 2). Thus, the endophyte was cultivated in this medium on a large scale (60 1) as a stationary culture and was then extracted with ethyl acetate and afterwards defatted with n-hexane to yield the final dried extract (12 g). Column chromatographic fractionation was performed on the methanolic extract starting with a solvent mixture composed of hexane and ethyl acetate in a proportion of 9 to 1. Polarity of the mobile phase was gradually increased till final elution with $100 \%$ ethyl acetate. Fractions collected were tested for antimicrobial activity in agar diffusion assays. Further purification steps were conducted on the bioactive fractions starting with Sephadex LH-20 and finally by preparative column chromatography using a solvent mixture of acetonitrile and water on reversed phase silica as a stationary phase which resulted in the isolation of four compounds.

From the HRESIMS of the first metabolite isolated compound 1 adominant peak at $\mathrm{m} / \mathrm{z} 557.1545[\mathrm{M}+\mathrm{H}]^{+}$ was detected for a molecular formula of $\mathrm{C}_{31} \mathrm{H}_{24} \mathrm{O}_{10}$. Six aromatic proton signals were observed in the proton nuclear magnetic resonance $\left({ }^{1} \mathrm{H}-\mathrm{NMR}\right)$ spectrum of which two represented methyl and three protons of a methoxy group. Furthermore, two signals for two 
hydroxyl protons were observed. Their chelation with neighboring carbonyl functional groups is suggested to be the reason for their observed downfield shift. 31 carbon signals were detected in the carbon-13 $\left({ }^{13} \mathrm{C}-\mathrm{NMR}\right)$ spectrum. Both the Distortionless enhancement by polarization transfer (DEPT) and ${ }^{13} \mathrm{C}-\mathrm{NMR}$ spectra indicated the presence of two methyl groups, six primary carbons and three methoxy groups. From the UV spectrum and the NMR spectra it was concluded that this natural product had the structure of a dimeric naphthopyrone. One part of the structure showed heteronuclear multiple bond correlation (HMBC) between the two protons (H-9' and H-7') which are Meta coupled. In addition, correlations were also observed between each of them and the quaternary carbon (C-10'). The second unit of the structure showed correlations of OH-8 with C-5'a, C-8' and C-9' and of OH-8 with C-4'a, C-5' and C-5'a. The proton (H-3) correlated similarly to the first part of the structure with $\mathrm{C}-2$ ' and the methyl carbon $\mathrm{CH}_{3}-2$. In addition, the proton signal corresponding to the aromatic proton (H-10') was correlated with C-4'a, C-4', C-5'a and C-10'a. These NMR data (Table 1 and Table 3) confirmed the two connected linear naphthopyrone moieties (fig. 3) of the compound. Comparison of these data with literature resulted in identification of the compound as dianhydroaurasperone C (1), previously isolated from the endophyte Aspergillus tubingensis of the plant Fallugia paradoxa ${ }^{[24]}$.

The second purified compound demonstrated the same mass and molecular formula of dianhydroaurasperone $\mathrm{C}$ by HRESIMS. It also showed similar NMR data (Table 1 and Table 3) and UV absorption spectrum in methanol to compound 1 which indicated that it was another naphthopyrone. In the ${ }^{1} \mathrm{H}$ NMR spectrum two signals for methyl protons were observed as well as three singlet signals for three methoxy protons. Additionally, six aromatic proton signals were detected. The DEPT spectrum showed the presence of six primary and five tertiary carbons. Furthermore, two chelating downfield shifted hydroxyl protons were represented by two singlet proton signals. Correlations were detected between (H-7) and C-5a as well as between (H-9) and C-5a, $\mathrm{C}-10$ and $\mathrm{C}-6$. The structure of the naphthalene moiety was deduced from the observed HMBC correlations between the hydroxyl group and C-4a, C-5 and C-5a. As for the pyrone ring $\mathrm{HMBC}$ correlations were found between the methyl protons $\left(\mathrm{CH}_{3}-2\right)$ and $\mathrm{C}-2$ and $\mathrm{C}-3$. The obtained HMBC correlations and ${ }^{13} \mathrm{C}-\mathrm{NMR}$ signals confirmed the dimeric nature of the compound. By comparing the deduced structure with previously
TABLE 3: ${ }^{13} \mathrm{C}$ NMR DATA (125 MHz, DMSO-D6) FOR DIANHYDROAURASPERONE C AND AURASPERONE D

\begin{tabular}{|c|c|c|}
\hline Position & $\begin{array}{c}\delta^{1} 3 \mathrm{C} \\
\text { (dianhydroaurasperone } \\
\text { C) }\end{array}$ & $\delta^{1} 3 c$ (aurasperone D) \\
\hline 2 & $168.8, \mathrm{qC}$ & $168.5, \mathrm{qC}$ \\
\hline 3 & $104.8, \mathrm{CH}$ & 105.6, CH \\
\hline 4 & 184.0, qC & 183.5, qC \\
\hline $4 a$ & 103.3, qC & 103.2, qC \\
\hline 5 & $160.5, q C$ & 161.2, qC \\
\hline $5 a$ & 108.7, qC & 107.6, qC \\
\hline 6 & $158.4, \mathrm{qC}$ & 158.5, qC \\
\hline 7 & 116.7, qC & $96.4, \mathrm{CH}$ \\
\hline 8 & $160.5, \mathrm{qC}$ & 157.8, qC \\
\hline 9 & 103.4, qC & 104.9, CH \\
\hline $9 a$ & 140.0, qC & $139.9, \mathrm{qC}$ \\
\hline 10 & 100.3, qC & 115.7, qC \\
\hline $10 a$ & 151.6, qC & 151.4, qC \\
\hline $\mathrm{CH}_{3}-2$ & $20.2, \mathrm{CH}_{3}$ & $20.2, \mathrm{CH}_{3}$ \\
\hline $\mathrm{OCH}_{3}-6$ & $61.4, \mathrm{OCH}_{3}$ & \\
\hline $\mathrm{OCH}_{3}-8$ & & $61.4, \mathrm{OCH}_{3}$ \\
\hline $2^{\prime}$ & 167.4, qC & $168.8, \mathrm{qC}$ \\
\hline $3^{\prime}$ & 105.3, CH & 106.7, CH \\
\hline $4^{\prime}$ & 183.9, qC & 183.9, qC \\
\hline 4'a & 106.5, qC & 103.3, qC \\
\hline $5^{\prime}$ & 159.5, qC & $160.4, \mathrm{qC}$ \\
\hline $5 ’ a$ & 107.5, qC & 108.5, qC \\
\hline $6^{\prime}$ & $160.4, \mathrm{qC}$ & 160.6, qC \\
\hline $7^{\prime}$ & $96.4, \mathrm{CH}$ & $96.7, \mathrm{CH}$ \\
\hline $8^{\prime}$ & 159.2, qC & $159.5, \mathrm{qC}$ \\
\hline 9' & 96.7, $\mathrm{CH}$ & $100.4, \mathrm{CH}$ \\
\hline 9’a & 140.1, qC & $139.4, \mathrm{qC}$ \\
\hline $10^{\prime}$ & 106.6, qC & 105.4, qC \\
\hline $10 ’ a$ & $149.5, \mathrm{qC}$ & 150.2, qC \\
\hline $\mathrm{CH}_{3}-2^{\prime}$ & $20.1, \mathrm{CH}_{3}$ & $20.1, \mathrm{CH}_{3}$ \\
\hline $\mathrm{OCH}_{3}-6^{\prime}$ & $55.2, \mathrm{OCH}_{3}$ & $55.0, \mathrm{OCH}_{3}$ \\
\hline $\mathrm{OCH}_{3}-8^{\prime}$ & $56.1, \mathrm{OCH}_{3}$ & $56.1, \mathrm{OCH}_{3}$ \\
\hline $\mathrm{OCH}_{3}-10^{\prime}$ & & \\
\hline
\end{tabular}

published data, it was found to be aurasperone D (2) (fig. 3), the toxic dimer reported as a metabolite of the fungus Aspergillus neoniger infecting mango fruits ${ }^{[25]}$.

A molecular formula of $\mathrm{C}_{32} \mathrm{H}_{26} \mathrm{O}_{10}$ was suggested by HRESIMS for the third secondary metabolite isolated from this endophytic fungus. Two methyl proton signals as well as four signals representing methoxy protons were detected in the ${ }^{1} \mathrm{H}$ NMR spectrum. Six signals for 


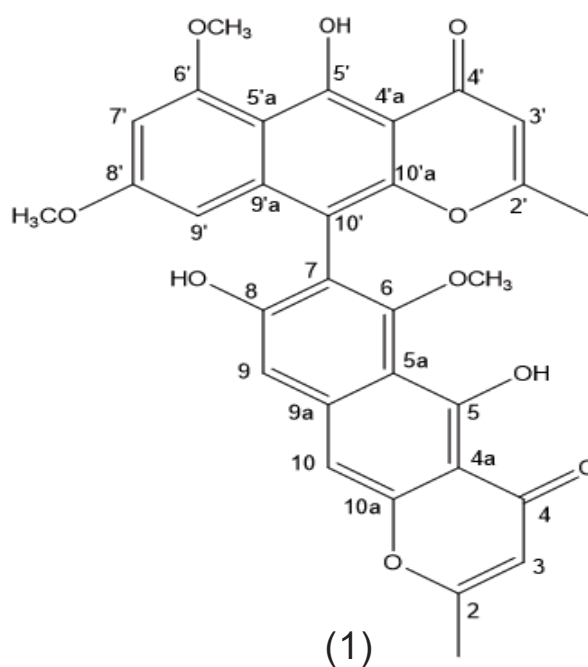

(1)

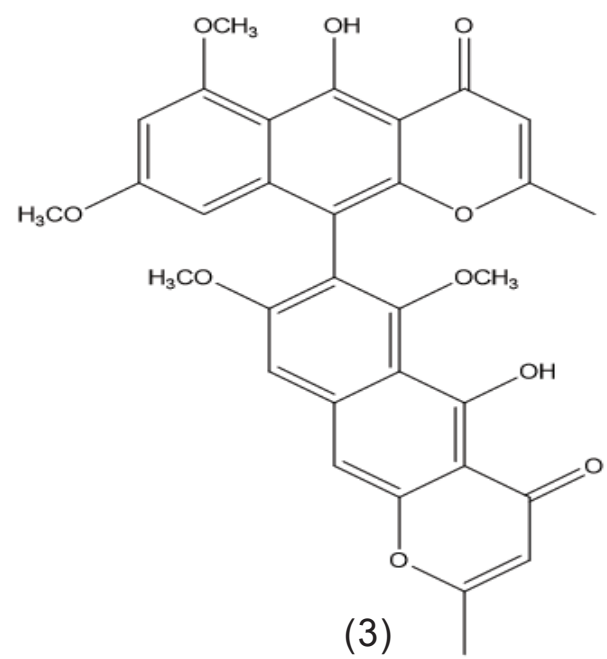

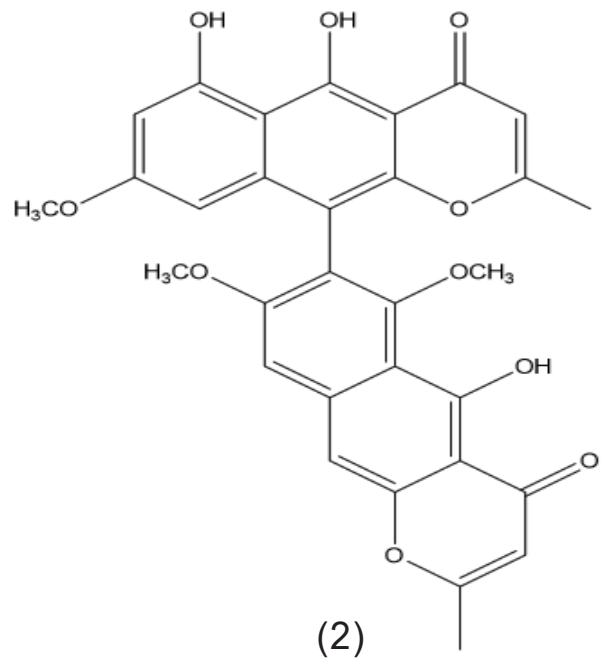

(2)

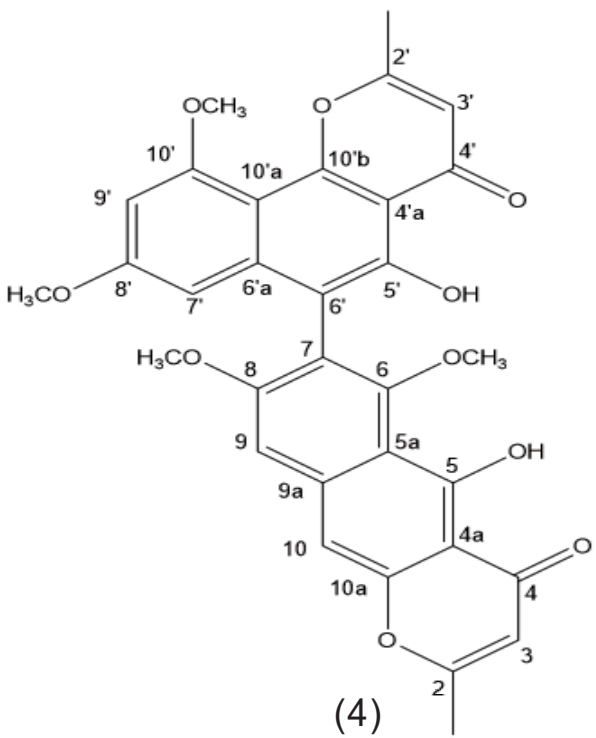

Fig. 3: Chemical structures of dianhydroaurasperone C (1), aurasperone D (2), aurasperone A (3) and asperpyrone D (4)

aromatic protons and two signals for chelating hydroxyl protons were observed. The spectroscopic data obtained showed close resemblance to that of aurasperone D. Only the appearance of a carbon signal at $\delta 54.9 \mathrm{ppm}$ for an additional methoxy group represents the main difference between aurasperone D and this compound (Table 1 and Table 4). Thus the structure presented in fig. 3 was deduced for this natural product, which was identified as aurasperone A (3) according to literature data $^{[24,25]}$.

The fourth secondary metabolite isolated was shown to possess a molecular formula of $\mathrm{C}_{31} \mathrm{H}_{24} \mathrm{O}_{10}$ by HRESIMS and ${ }^{13} \mathrm{C}$-NMR spectroscopy. A downfield shift of the hydroxyl proton signals indicated their conjugation with carbonyl functional groups. The UV spectrum of this secondary metabolite as well as the ${ }^{1} \mathrm{H}$ and ${ }^{13} \mathrm{C}$ NMR spectra showed close similarity to aurasperone A and D. These spectroscopic data indicated the structure of a dimeric naphthopyrone for this natural product. 31 carbon signals appeared in the ${ }^{13} \mathrm{C}-\mathrm{NMR}$ spectrum which included two methyl, three methoxy, six methine and 20 quaternary carbons. The ${ }^{1} \mathrm{H}-\mathrm{NMR}$ spectrum revealed the presence of two methyl singlets, three methoxy singlets, six aromatic protons as well as two phenolic hydroxyls. HMBC correlations were observed for the first naphthopyrone unit of this natural product which were identical to those of aurasperone $\mathrm{A}^{[26,27]}$. The linear arrangement of its naphthopyrone moiety was concluded from HMBC correlations detected for the proton signal (H-10') with the carbon signals of C-10'a, C-4a, C-5a and C-4 (Table 1 and Table 4). The NMR data of the second unit of the compound together with comparisons with previously published data confirmed the identity of this natural product as asperpyrone D (4) (fig. 3) ${ }^{[28]}$. 
TABLE 4: ${ }^{13} \mathrm{C}$ NMR DATA (125 MHz, DMSO-D6) FOR AURASPERONE A AND ASPERPYRONE D

\begin{tabular}{|c|c|c|}
\hline Position & $\delta^{13} \mathrm{c}$ (Aurasperone A) & $\delta^{13} \mathrm{C}$ (Asperpyrone D) \\
\hline 2 & $168.8, \mathrm{qC}$ & $168.0, \mathrm{qC}$ \\
\hline 3 & $105.8, \mathrm{CH}$ & 105.7, CH \\
\hline 4 & 183.9, qC & 184.1, qC \\
\hline $4 a$ & 103.9, qC & 103.4, qC \\
\hline 5 & 160.9, qC & 161.2, qC \\
\hline $5 a$ & 108.2, qC & 109.8, qC \\
\hline 6 & $159.9, \mathrm{qC}$ & $157.1, \mathrm{qC}$ \\
\hline 7 & 117.2, qC & 116.8, qC \\
\hline 8 & 159.8, qC & 152.7, qC \\
\hline 9 & 103.1, CH & $105.2, \mathrm{CH}$ \\
\hline $9 a$ & 139.9, qC & $140.0 \mathrm{qC}$ \\
\hline 10 & $101.4, \mathrm{CH}$ & $100.4, \mathrm{CH}$ \\
\hline $10 a$ & $150.1, \mathrm{qC}$ & 152.3, qC \\
\hline $\mathrm{CH}_{3}-2$ & $20.1, \mathrm{CH}_{3}$ & $20.1, \mathrm{CH}_{3}$ \\
\hline $\mathrm{OCH}_{3}-6$ & $61.2, \mathrm{OCH}_{3}$ & $61.2, \mathrm{OCH}_{3}$ \\
\hline $\mathrm{OCH}_{3}-8$ & $61.3, \mathrm{OCH}_{3}$ & \\
\hline $2^{\prime}$ & 167.9, qC & 168.0, qC \\
\hline 3' & 105.7, CH & 109.7, CH \\
\hline $4^{\prime}$ & 184.0, qC & 182.4, qC \\
\hline 4'a & 103.2, qC & 106.7, qC \\
\hline 5' & 161.2, qC & 154.6, qC \\
\hline 5 'a & 104.9, qC & 105.6, qC \\
\hline $6^{\prime}$ & $158.6, \mathrm{qC}$ & $139.9, \mathrm{qC}$ \\
\hline 7' & $96.5, \mathrm{CH}$ & $95.8, \mathrm{CH}$ \\
\hline $8^{\prime}$ & 159.5, qC & 152.8, qC \\
\hline 9' & 96.6, qC & $96.9, \mathrm{CH}$ \\
\hline 9’a & 139.5, qC & 158.9, qC \\
\hline $10^{\prime}$ & 110.4, qC & 103.8, qC \\
\hline $10 ’ a$ & 151.6, qC & 154.9, qC \\
\hline $\mathrm{CH}_{3}-2^{\prime}$ & $20.2, \mathrm{CH}_{3}$ & $20.2, \mathrm{CH}_{3}$ \\
\hline $\mathrm{OCH}_{3}-6^{\prime}$ & $55.1, \mathrm{OCH}_{3}$ & \\
\hline $\mathrm{OCH}_{3}-8^{\prime}$ & $56.3, \mathrm{OCH}_{3}$ & $56.2, \mathrm{OCH}_{3}$ \\
\hline $\mathrm{OCH}_{3}-10$ & & $56.4, \mathrm{OCH}_{3}$ \\
\hline
\end{tabular}

The isolated compounds were tested for antimicrobial activity in agar diffusion assay against several test strains (Penicillium notatum, Penicillium avelaneum, Aspergillus terreus, Bacillus subtilis, Escherichia coli, Staphylococcus aureus) using nystatin and ciprofloxacin as positive controls of antifungal and antibacterial activity respectively. Results showed that highest antibacterial and antifungal activities were observed for compound 2 and 4 while compound 1 and 3 showed rather weak antimicrobial effects (fig. 4 and fig. 5). Additionally, compounds 2 and 4 were examined for antifungal effect against Fusarium oxysporum, a common pathogen of many plants. Results revealed
MIC values of 67 and $76 \mu \mathrm{g} \mathrm{ml} \mathrm{m}^{-1}$ for compounds 2 and 4, respectively. This result suggests potential protection exerted by the endophyte to its host plant. This assumption has been recently supported by the discovered antifungal activity of bacterial endophytes of Phoenix dactylifera against several phytopathogenic agents ${ }^{[29]}$. Furthermore, they were subjected to a cytotoxic assay against the cancer cell lines K-562, HUVEC and HeLa. Dianhydroaurasperone C (1) exerted weak antimicrobial activity against the tested microbial strains. It also showed weak anticancer activity against all tested cell lines (fig. 6, fig. 7 and fig. 8). These findings are in agreement with previous studies about this metabolite reporting the lack of anticancer activity for it against several cancer cell lines ${ }^{[30]}$. Studies performed on aurasperone D (2) revealed its central nervous system depressant action that lead to death after respiratory failure ${ }^{[25]}$. Investigation

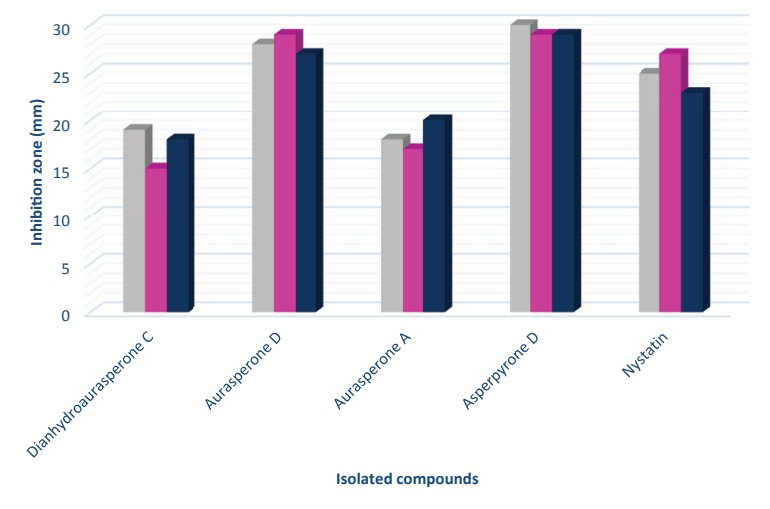

Fig. 4: Antifungal activities of the compounds 1-4

Antifungal activity is measured in terms of the diameter of the inhibition zone in millimeters. Activities were tested against

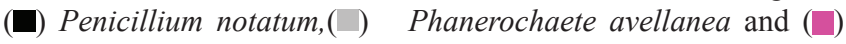
Aspergillus terreus

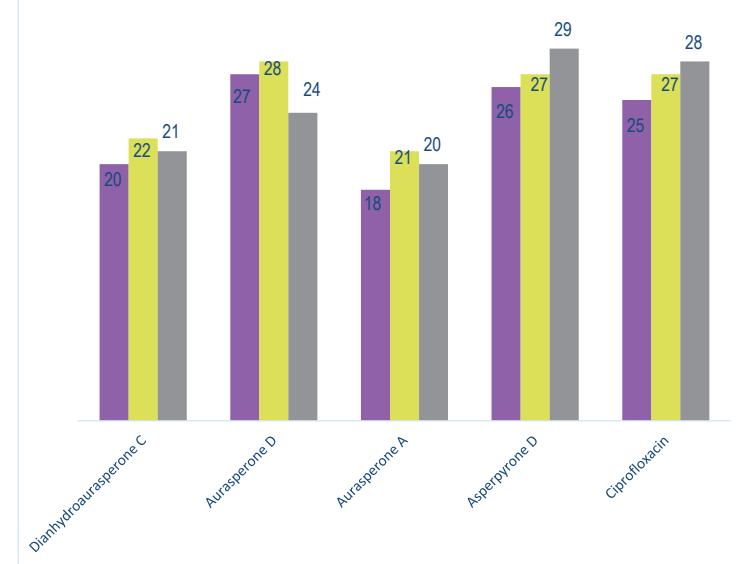

Fig. 5: Antibacterial activity of compounds 1-4.

Antibacterial activity is measured in terms of the diameter of the inhibition zone in millimeters. Activities were tested against ( $\square$ )

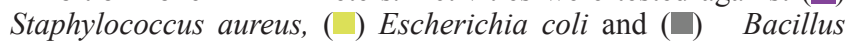
subtilis 
of its cytotoxic activity in our study revealed strong cytotoxic effects for this natural product against $\mathrm{HeLa}$ cell line with a $\mathrm{CC}_{50}$ of $4.4 \mu \mathrm{g} \mathrm{ml}^{-1}$ and significant anti proliferative activity against K-562 and HUVEC cell lines with a $\mathrm{GI}_{50}$ of 5.4 and $5.7 \mu \mathrm{g} \mathrm{ml}^{-1}$, respectively (fig. 6, fig. 7 and fig. 8).

Aurasperone A (3) on the contrary exerted weak anticancer activities against all tested cell lines (fig. 6, fig. 7 and fig. 8). In previously published studies asperpyrone D (4) was stated to exhibit neither cytotoxic nor antimicrobial activities ${ }^{[28]}$. Our investigation of its antimicrobial action revealed slightly different results as weak antibacterial and antifungal activities against the selected test strains in agar diffusion assay were observed for it (fig. 4 and fig. 5). Furthermore, this metabolite exerted significant cytotoxicity against HeLa cancer cell by exhibiting a $\mathrm{CC}_{50}$ of $3.0 \mu \mathrm{g} \mathrm{ml}^{-1}$

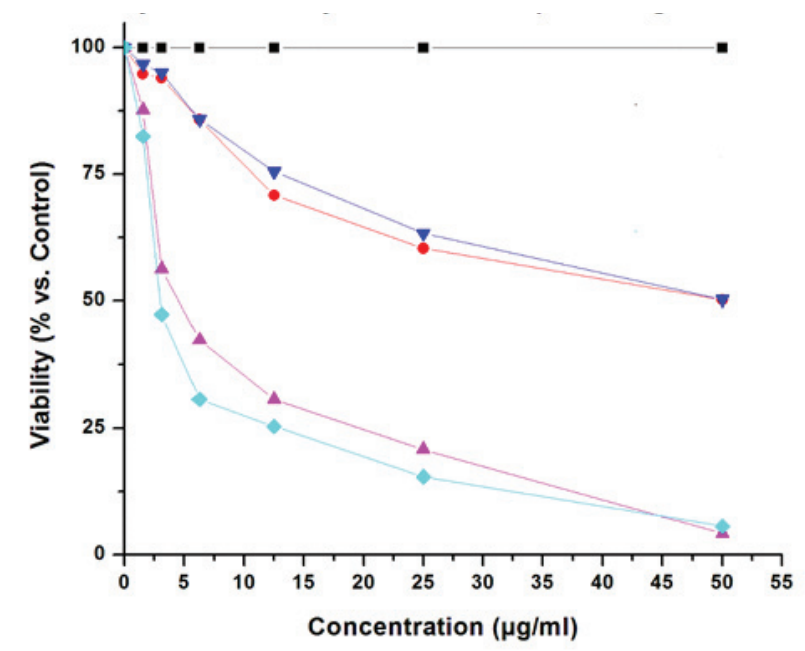

Fig. 6: Cytotoxic activity of compound 1, compound 2, compound 3, and compound 4 against HeLa cell line compared to negative control.

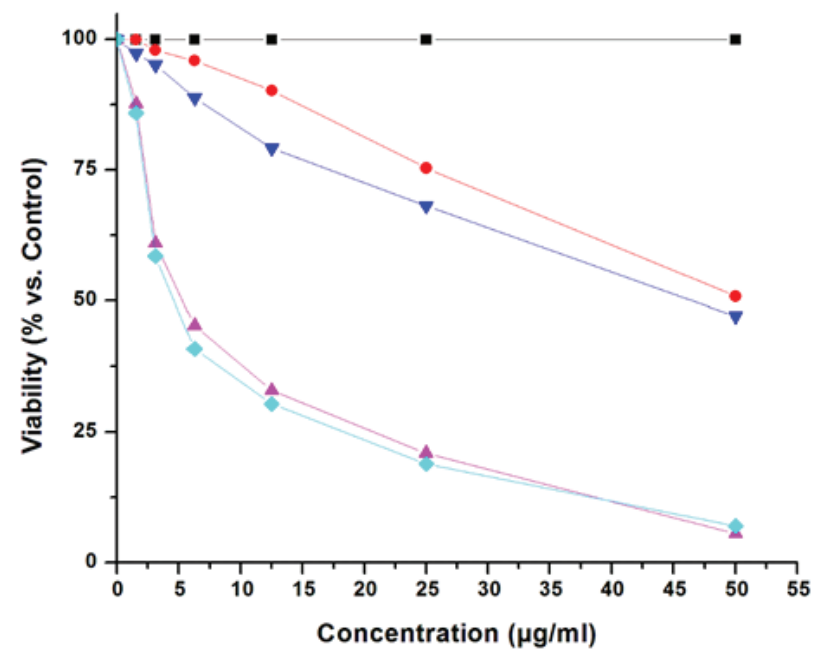

Fig. 7: Antiproliferative activity of compound 1, compound 2 , compound 3 and compound 4 against K-562 cell line compared to negative control

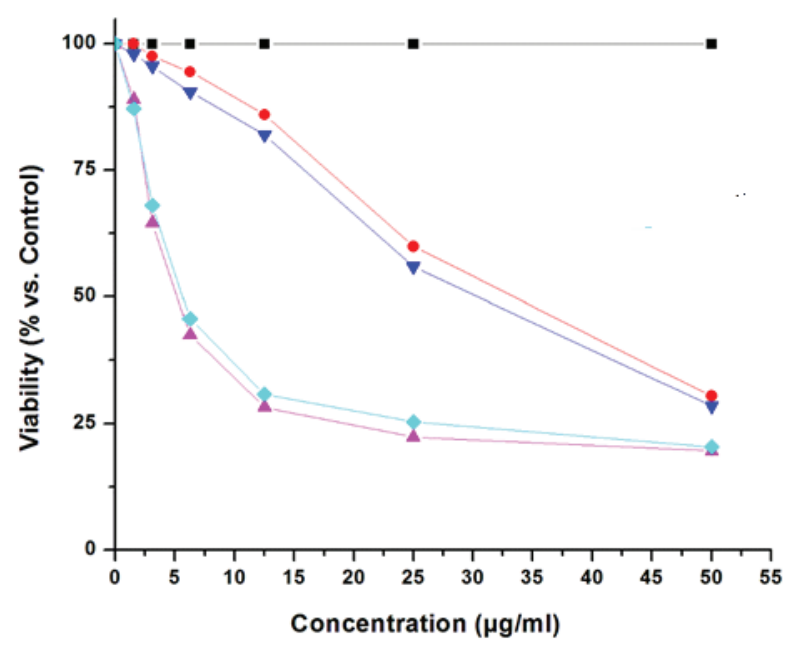

Fig. 8: Antiproliferative activity of compound1; compound 2; compound 3; and compound 4 against HUVEC cell line compared to negative control

and strong antiproliferative activities against both K-562 and HUVEC cancer cells with $\mathrm{GI}_{50}$ of 4.7 and $5.9 \mu \mathrm{g} \mathrm{ml}{ }^{-1}$, respectively (fig. 6, fig. 7 and fig. 8). The detected antimicrobial effects of compounds 2 and 4 suggest potential protective effect exerted by this endophyte to its host plant which supports previous assumptions on the protective relationship of endophytes with their host plants ${ }^{[1]}$. It also suggests possible contribution of this endophyte in the reported anticancer and antimicrobial activities of the host plant. Additionally, potential application of these natural products in agricultural purposes is also suggested and needs to be further studied.

In conclusion an Aspergillus neoniger species has been isolated from the leaves of the medicinal plant Ficus carica family Moraceae growing in Makkah region, KSA and was investigated for its biologically active metabolites. Four aurasperones were isolated from it and identified by spectroscopic analysis. Two of the identified compounds, aurasperone D and asperpyrone D exerted significant anticancer effects against HUVEC, HeLa and K-562 cell lines in addition to antimicrobial effects against several fungal and bacterial strains. The other two natural products, dianhydroaurasperone $\mathrm{C}$ and aurasperone A exerted weak anticancer and antimicrobial activities. The detected antifungal activities of asperpyrone D and aurasperone D against the phytopathogen Fusarium oxysporum suggests potential protection provided by this endophyte to its host plant against invading microbes and the observed anticancer and antimicrobial activities of these endophytic metabolites suggest partial contribution of the endophyte in the reported activities of the host plant. 


\section{Acknowledgements:}

Authors are thankful to the Deanship of Scientific Research at Umm Al-Qura University for funding this study through a grant coded: 19-MED-1-03-0005.

\section{Conflict of Interests:}

The authors declared no conflict of interest.

\section{REFERENCES}

1. Tan RX, Zou WX. Endophytes: a rich source of functional metabolites. Nat Prod Rep 2001;18(4):448-59.

2. Berdy J. Bioactive microbial metabolites. J Antibiot 2005;58(1):1-26.

3. Aly AH, Edrada-Ebel R, Indriani ID, Wray V, Muller WE, Totzke F, et al. Cytotoxic metabolites from the fungal endophyte Alternaria sp. and their subsequent detection in its host plant Polygonum senegalense. J Nat Prod 2008;71(6):972-80.

4. Schulz B, Boyle C. The endophytic continuum. Mycol Res 2005;109(6):661-86.

5. Strobel G. Harnessing endophytes for industrial microbiology. Curr Opin Microbiol 2006;9(3):240-4.

6. Joseph B, Raj SJ. Pharmacognostic and phytochemical properties of Ficus carica Linn-An overview. 2011;3(1):8-12.

7. Vieira LM, Kijjoa A. Naturally-occurring xanthones: recent developments. Curr Med Chem 2005;12(21):2413-46. Int J Pharmtech Res

8. Abdel-Hameed ES. Total phenolic contents and free radical scavenging activity of certain Egyptian Ficus species leaf samples. Food Chem 2009;114(4):1271-7.

9. Backes E, Leichtweis MG, Pereira C, Carocho M, Barreira JC, Genena AK, et al. Ficus carica L. and Prunus spinosa L. extracts as new anthocyanin-based food colorants: A thorough study in confectionery products. Food Chem 2020;333:127457.

10. Di Pierro G, O'Keeffe MB, Poyarkov A, Lomolino G, FitzGerald RJ. Antioxidant activity of bovine casein hydrolysates produced by Ficus carica L.-derived proteinase. Food Chem 2014;156:305-11.

11. Herre EA, Jander KC, Machado CA. Evolutionary ecology of figs and their associates: recent progress and outstanding puzzles. Annu Rev Ecol Evol Syst 2008;39:439-58.

12. Abd El Raheim MD, Soliman GA, Zaghloul AM, Alqasoumi SI, Awaad AS, Radwan AM, et al. Chemical constituents and protective effect of Ficus ingens (Miq.) Miq. on carbon tetrachloride-induced acute liver damage in male Wistar albino rats. J Saudi Chem Soc 2013;17(1):125-33.

13. Suryanarayanan TS, Vijaykrishna D. Fungal endophytes of aerial roots of Ficus benghalensis. Fungal Divers 2001;8:15561.

14. Rosli NM, Ashari KI, Azmi NS. Isolation and preliminary screening of endophytic fungi from Ficus carica for biocontrol and phosphate solubilization. Environ Ecosyst Sci 2020;4(2):77-84.

15. Rana KL, Kour D, Kaur T, Devi R, Negi C, Yadav AN, et al. Endophytic fungi from medicinal plants: biodiversity and biotechnological applications. Microb Endophytes 2020;273305.
16. Jeong MR, Kim HY, Cha JD. Antimicrobial activity of methanol extract from Ficus carica leaves against oral bacteria. J Bacteriol Virol 2009;39(2):97-102.

17. Aref HL, Salah KB, Chaumont JP, Fekih A, Aouni M, Said K. In vitro antimicrobial activity of four Ficus carica latex fractions against resistant human pathogens (antimicrobial activity of Ficus carica latex). Pak J Pharm Sci 2010;23(1):538.

18. Purnamasari R, Winarni D, Permanasari AA, Agustina E, Hayaza S, Darmanto W. Anticancer activity of methanol extract of Ficus carica leaves and fruits against proliferation, apoptosis, and necrosis in Huh7it cells. Cancer Inform 2019;18:1-7.

19. Abdou R, Scherlach K, Dahse HM, Sattler I, Hertweck C. Botryorhodines A-D, antifungal and cytotoxic depsidones from Botryosphaeria rhodina, an endophyte of the medicinal plant Bidens pilosa. Phytochemistry 2010;71(1):110-6.

20. Jariwala B, Desai B. Isolation and identification of endophytic fungi from various medicinal plants. $\mathrm{Bmr}$ Microbiol 2018;4(1):1-7.

21. Wayne PA. Reference method for broth dilution antifungal susceptibility testing of yeasts, approved standard. CLSI document M27-A2, USA; 2002.

22. Afonin S, Glaser RW, Berditchevskaia M, Wadhwani P, Guhrs $\mathrm{KH}$, Mollmann U, et al. 4-Fluorophenylglycine as a Label for 19F NMR Structure Analysis of Membrane-Associated Peptides. ChemBioChem 2003;4(11):1151-63.

23. Macabeo AP, Lopez AD, Schmidt S, Heilmann J, Dahse HM, Alejandro GJ, et al. Antitubercular and cytotoxic constituents from Goniothalamus gitingensis. Rec Nat Prod 2014;8(1):415 .

24. Akiyama K, Teraguchi S, Hamasaki Y, Mori M, Tatsumi $\mathrm{K}$, Ohnishi K, et al. New Dimeric Naphthopyrones from Aspergillus niger. J Nat Prod 2003;66(1):136-9.

25. Ghosal S, Biswas K, Chakrabarti DK. Toxic naphthogamma-pyrones from Aspergillus niger. J Agric Food Chem 1979;27(6):1347-51.

26. Rosenblueth M, Martinez-Romero E. Bacterial endophytes and their interactions with hosts. Mol Plant Microbe Interact 2006;19(8):827-37.

27. He G, Matsuura H, Yoshihara T. Isolation of an $\alpha$-methylene$\gamma$-butyrolactone derivative, a toxin from the plant pathogen Lasiodiplodia theobromae. Phytochemistry 2004;65(20):28037.

28. Zhan J, Gunaherath GK, Wijeratne EK, Gunatilaka AL. Asperpyrone D and other metabolites of the plant-associated fungal strain Aspergillus tubingensis. Phytochemistry 2007;68(3):368-72.

29. Slama HB, Cherif-Silini H, Chenari Bouket A, Qader M, Silini A, Yahiaoui B, et al. Screening for Fusarium antagonistic bacteria from contrasting niches designated the endophyte Bacillus halotolerans as plant warden against Fusarium. Front Microbiol 2019;9:3236.

30. Ikeda SI, Sugita M, Yoshimura A, Sumizawa T, Douzono H, Nagata $\mathrm{Y}$, et al. Aspergillus species strain $\mathrm{m} 39$ produces two naphtho- $\gamma$-pyrones that reverse drug resistance in human $\mathrm{KB}$ cells. Int J Cancer 1990;45(3):508-13. 